\title{
Short communication: Monitoring nutritional quality of Amiata donkey milk: Effects of lactation and productive season
}

\author{
Mina Martini, ${ }^{* 1}$ Iolanda Altomonte, $†$ Federica Salari, $†$ and Anna M. Carolił \\ *Dipartimento di Scienze Veterinarie, Università di Pisa, Pisa, 56100 Italy \\ †Centro di Ricerche Agro-Ambientali Enrico Avanzi, San Piero a Grado, Pisa, 56122 Italy \\ fDipartimento di Medicina Molecolare e Translazionale, Università degli Studi di Brescia, Brescia, 25123 Italy
}

\section{ABSTRACT}

Milk nutritional characteristics are especially interesting when donkey milk is aimed at consumption by children and the elderly. The aim of this study was to monitor the nutritional quality of Amiata donkey milk during lactation and productive season to provide information on the milk characteristics and to study action plans to improve milk yield and quality. Thirty-one pluriparous jennies belonging to the same farm were selected. Individual samples of milk from the morning milking were taken once per month starting from the d 30 of lactation until d 300. Milk yield and dry matter, fat, and ash content were constant throughout the experimental period. Milk total protein content showed a progressive decrease during the first 6 mo of lactation; after this period, the protein percentages remained constant (1.50\%). Caseins and lactose were lower until d 60 of lactation and remained constant thereafter. During summer and autumn, milk yield and casein and lactose contents were higher, whereas during the spring season, higher protein and ash contents were found. The percentages of fat and dry matter were stable as were most of the minerals in the milk, except for calcium, which was higher in the spring. In conclusion, Amiata donkey milk was found to be relatively stable during lactation. This is an advantage in terms of the production and trade of a food product with consistent characteristics. The different milk yield and quality during the productive seasons were probably related to better adaptability of the animals to warm and temperate periods.

Key words: Amiata donkey milk, nutritional quality, lactation, season

\section{Short Communication}

Despite the small-scale production, donkey milk (DoM) has recently been of particular interest in the

\footnotetext{
Received June 30, 2014.

Accepted July 29, 2014.

${ }^{1}$ Corresponding author: mina.martini@unipi.it
}

scientific and husbandry fields (Martini et al., 2014a,b). In fact, clinical studies have shown that it is an effective treatment for allergies to cow milk proteins or in cases of multiple food intolerance (Monti et al., 2007).

In addition, DoM has beneficial effects in terms of the energy balance, lipid metabolism, prevention of diseases (Jirillo et al., 2010; Lionetti et al., 2012), and it is considered as a "functional food" (Ivanković et al., 2009). Given the quality of DoM, rearing this adaptable and low-maintenance-cost species could be a source of income for many marginal areas and help safeguard endangered breeds.

In central Italy, a native donkey breed, Amiata (or Amiatino), is reared. The name is derived from the traditional farming area of Mount Amiata (Tuscany, Italy). The population was once reared as working animals, but agricultural industrialization brought the population near to extinction. Only recently have measures to safeguard the population been introduced, and the Amiata donkey is now used for donkey rides, pet therapy, and also for milk production. Recently, a project in Tuscany has created a DoM chain for human consumption, and also focused milk production on cosmetics and probiotics.

Milk production varies depending on genetic, environmental, and physiological factors. However, cow milk is mostly standardized, whereas DoM has high variability in terms of its components (Claeys et al., 2014). In addition, variations in the quality of DoM as a result of physiological factors, such as the distance from delivery, have been poorly studied and little is known about the changes that occur in the quality of Amiata DoM during lactation. We evaluated the quality of Amiata DoM, focusing on the physiological stage of lactation and on the season to better understand milk characteristics and to study action plans to improve milk yields and quality.

Thirty-one pluriparous ( $9 \pm 2$ yr old) Amiata jennies belonging to the same farm were selected. The jennies were raised outdoors in a free animal-housing system with an indoor rest area. The animals had a BCS of 4.9 (Pearson and Ouassat, 2000) and were fed ad libitum 
mixed grass hay and about $2.5 \mathrm{~kg} / \mathrm{d}$ per head of commercial pelleted concentrate (Progeo Società Cooperativa Agricola, Reggio Emilia, Italy) for dairy jennies.

Animals had free access to clean and fresh water. The jennies were routinely machine milked by a wheeled trolley milking machine (DeLaval S.p.A., San Donato Milanese, Italy). Foals were separated from the dams 3 to $3.5 \mathrm{~h}$ before the first milking according to Salimei et al. (2004). Individual samples of milk from the morning milking were taken once per month starting from d 30 of lactation until d 300 .

Milk samples were taken to the laboratory in tanks at $4^{\circ} \mathrm{C}$. The following parameters were evaluated on fresh DoM samples: DM, fat, and lactose contents by infrared analysis (MilkoScan; Italian Foss Electric, Padova, Italy), and proteins, caseins, ash, Ca, P, K, Na, $\mathrm{Mg}$, and Zn, using methods of the Association of Official Analytical Chemists (AOAC, 1990). The results of the milk composition were analyzed using ANOVA for repeated measurements, considering the sampling time and the production season as fixed effects and the subject as a random effect. Least significance means were compared by $t$-test. Significant differences were considered at $P<0.01$. Statistical analysis was carried out using JMP software (SAS Institute, 2002).

Table 1 shows the changes in the composition of the Amiata DoM during lactation. The milk yield was constant throughout the experimental period, showing only a slight and not significant increase between d 60 and 90 after delivery. In Martina Franca (Salimei and Fantuz, 2012) and Ragusano jennies (Bordonaro et al., 2013) the average milk yield has been determined to decline during lactation and to subsequently stabilize up to mo 8 to 10 of lactation.

Although a comparison with cow milk goes beyond the aim of the present study, it can be pointed out that DM, fat, proteins, casein, and ash contents were lower in DoM compared with cow milk, whereas lactose content was higher (Barłowska et al., 2011; Cosentino et al., 2012). Furthermore, DoM was for some parameters more similar to human than cow milk.

As observed in the donkeys of Southern Italy, Amiata donkey DM and fat content also did not undergo significant changes during lactation. However, fat content in Amiata jennies showed an intermediate range (0.30$0.44 \%)$ between the range reported for Martina Franca $(0.42-0.72 \%)$ and Ragusano jennies (0.11-0.19\%) during lactation (Salimei et al., 2004; Cosentino et al., 2012; Martemucci and D'Alessandro, 2012; Bordonaro et al., 2013). These differences may be due to the origin of the breed.

In the first 6 mo of lactation, we found a progressive and significant decrease in the protein content $(P$ $<0.01$ ); after this period the protein percentage was

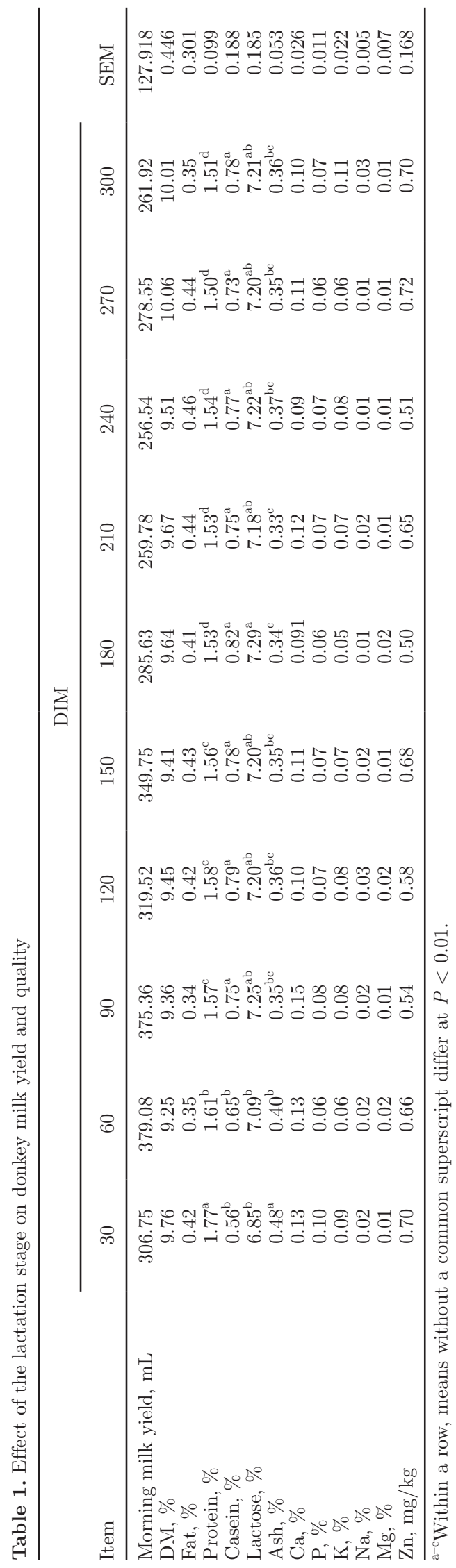


Table 2. Effect of the season on donkey milk yield and quality

\begin{tabular}{lccccc}
\hline & \multicolumn{5}{c}{ Season } \\
\cline { 2 - 5 } Item & Autumn & Winter & Spring & Summer & SEM \\
\hline Morning milk yield, mL & $318.58^{\mathrm{ab}}$ & $253.60^{\mathrm{b}}$ & $273.17^{\mathrm{b}}$ & $391.31^{\mathrm{a}}$ & 127.918 \\
DM, \% & 9.36 & 9.97 & 9.72 & 9.33 & 0.446 \\
Fat, \% & 0.43 & 0.56 & 0.53 & 0.39 & 0.301 \\
Protein, \% & $1.55^{\mathrm{b}}$ & $1.54^{\mathrm{c}}$ & $1.64^{\mathrm{a}}$ & $1.57^{\mathrm{b}}$ & 0.099 \\
Casein, \% & $0.83^{\mathrm{a}}$ & $0.67^{\mathrm{b}}$ & $0.67^{\mathrm{b}}$ & $0.83^{\mathrm{a}}$ & 0.188 \\
Lactose, \% & $7.23^{\mathrm{a}}$ & $7.19^{\mathrm{a}}$ & $7.05^{\mathrm{b}}$ & $7.24^{\mathrm{a}}$ & 0.185 \\
Ash, \% & $0.36^{\mathrm{b}}$ & $0.34^{\mathrm{b}}$ & $0.41^{\mathrm{a}}$ & $0.38^{\mathrm{ab}}$ & 0.053 \\
Ca, \% & $0.09^{\mathrm{c}}$ & $0.11^{\mathrm{c}}$ & $0.13^{\mathrm{a}}$ & $0.11^{\mathrm{b}}$ & 0.026 \\
P, \% & 0.07 & 0.06 & 0.07 & 0.07 & 0.011 \\
$\mathrm{~K}, \%$ & 0.06 & 0.08 & 0.05 & 0.08 & 0.022 \\
$\mathrm{Na}, \%$ & 0.02 & 0.02 & 0.01 & 0.02 & 0.005 \\
$\mathrm{Mg}, \%$ & 0.01 & 0.01 & 0.02 & 0.02 & 0.007 \\
Zn, mg/kg & 0.51 & 0.64 & 0.78 & 0.60 & 0.168 \\
\hline
\end{tabular}

${ }^{\mathrm{a}-\mathrm{c}}$ Within a row, means without a common superscript differ at $P<0.01$.

constant (1.50\%). A progressive decreasing trend in milk protein content during lactation has been reported by other investigations on DoM (Giosuè et al., 2008; Bordonaro et al., 2013).

Although protein contents were higher during the first 6 mo of lactation, casein contents were lower $(P$ $<0.01$ ) until d 60 of lactation and remained constant thereafter. This could indicate a different distribution of the nitrogenous components of milk during lactation, possibly linked to a higher percentage of NPN in the first 2 mo of lactation, as observed by Guo et al., (2007).

Lactose content was lower $(P<0.01)$ in the first 60 $\mathrm{d}$ of lactation and then remained fairly constant during lactation, with a maximum peak at $180 \mathrm{~d}$ after delivery. Similar trends were also reported by Guo et al. (2007).

Finally, ash content was found to have a decreasing trend, consistent with reports by other authors (Guo et al., 2007; Salimei and Fantuz, 2012). In our study, this decrease did not correspond to a significant decrease in individual mineral elements, which were constant during lactation. In contrast, Fantuz et al. (2012) reported significant changes in some minerals in Martina Franca DoM. Their results may be due to the length of the lactation period considered in the study, and also to the breed (Gaucheron, 2005).

Our results indicate that Amiata DoM is quite stable during lactation, which could be an advantage for its production and commercialization. However, although the stage of lactation had little effect on the chemical composition of the milk, the production season had effects on some parameters. As shown in Table 2, in summer and autumn, milk yield and casein and lactose contents were higher $(P<0.01)$, whereas higher $(P<0.01)$ protein and ash percentages were found in spring. Our results on milk yield are in agreement with a study by Cosentino et al. (2012), who observed greater quantities of milk and higher percentages of lactose during summer compared with spring milk in asses from Southern Italy. In contrast, Bordonaro et al. (2013) reported higher milk yield and proteins in winter and in autumn in Ragusano jennies. The seasonal differences we found may be related both to the different latitude of the farming areas and the response to the environmental conditions linked to the breeds' origin. Although little information exists on the effect of cold stress on the donkey (Ayo et al., 2013), thermal stress in dairy animals negatively affects the quantity and quality of milk (Bernabucci et al., 2010). Moreover, some features of the Amiata breed, such as the scapular cross and the zebra stripes, suggest that it descended directly from the African donkey (Sargentini et al., 2012); thus, the Amiata origin would indicate good adaptation to a warm climate.

Fat and DM percentages were stable, as were most of the minerals in the milk (Table 2), except for calcium, which was higher $(P<0.01)$ in spring.

In conclusion, Amiata donkey milk did not show large variability in the quality or amount of milk produced during lactation. These features could be an advantage for its production and marketing in terms of it having consistent quality. The homogeneous nutritional characteristics are especially interesting when the milk is aimed at consumption by children and the elderly. The changes in milk production and quality during the productive seasons were probably related to better adaptability of the animals to warm and temperate periods.

\section{REFERENCES}

AOAC (Association of Official Analytical Chemists). 1990. Official Methods of Analysis. 15th ed. AOAC, Arlington, VA. 
Ayo, J. O., F. H. Olaifa, and A. S. Ake. 2013. Physiological responses of donkeys (Equus asinus, Perissodactyla) to work stress and potential ameliorative role of ascorbic acid. Afr. J. Biotechnol. 12:1585-1593.

Barłowska, J., M. Szwajkowska, Z. Litwińczuk, and J. Król. 2011. Nutritional value and technological suitability of milk from various animal species used for dairy production. Comp. Rev. Food Sci. Food Safety 10:291-302.

Bernabucci, U., N. Lacetera, L. H. Baumgard, R. P. Rhoads, B. Ronchi, and A. Nardone. 2010. Metabolic and hormonal acclimation to heat stress in domesticated ruminants. Animal 4:1167-1183.

Bordonaro, S., C. Dimauro, A. Criscione, D. Marletta, and N. P. P. Macciotta. 2013. The mathematical modeling of the lactation curve for dairy traits of the donkey (Equus asinus). J. Dairy Sci. 96:4005-4014.

Claeys, W. L., C. Verraes, S. Cardoen, J. De Block, A. Huyghebaert, K. Raes, K. Dewettinck, and L. Herman. 2014. Consumption of raw or heated milk from different species: An evaluation of the nutritional and potential health benefits. Food Contr. 42:188-201.

Cosentino, C., R. Paolino, P. Freschi, and A. M. Calluso. 2012. Jenny milk production and qualitative characteristics. J. Dairy Sci. 95:2910-2915.

Fantuz, F., S. Ferraro, L. Todini, R. Piloni, P. Mariani, and E. Salimei. 2012. Donkey milk concentration of calcium, phosphorus, potassium, sodium and magnesium. Int. Dairy J. 24:143-145.

Gaucheron, F. 2005. The minerals of milk. Reprod. Nutr. Dev. $45: 473-483$

Giosuè, C., M. Alabiso, G. Russo, M. L. Alicata, and C. Torrisi. 2008. Jennet milk production during the lactation in a Sicilian farming system. Animal 2:1491-1495.

Guo, H. Y., K. Pang, X. Y. Zhang, L. Zhao, S. W. Che, M. L. Dong, and F. Z. Ren. 2007. Composition, physiochemical properties, nitrogen fraction distribution and amino acid profile of donkey milk. J. Dairy Sci. 90:1635-1643.

Ivanković, A., J. Ramljak, I. Štulina, N. Antunac, I. Bašić, N. Kelava, and M. Konjačić. 2009. Characteristics of the lactation, chemical composition and milk hygiene quality of the Littoral-Dinaric ass. Mljekarstvo 59:107-113.

Jirillo, F., E. Jirillo, and T. Magrone. 2010. Donkey's and goat's milk consumption and benefits to human health with special reference to the inflammatory status. Curr. Pharm. Des. 16:859-863.
Lionetti, L., G. Cavaliere, P. Bergamo, G. Trinchese, C. De Filippo, G. Gifuni, M. Gaita, A. Pignalosa, I. Donizzetti, R. Putti, R. Di Palo, A. Barletta, and M. P. Mollica. 2012. Diet supplementation with donkey milk upregulates liver mitochondrial uncoupling, reduces energy efficiency and improves antioxidant and antiinflammatory defences in rats. Mol. Nutr. Food Res. 56:1596-1600.

Martemucci, G., and A. G. D'Alessandro. 2012. Fat content, energy value and fatty acid profile of donkey milk during lactation and implications for human nutrition. Lipids Health Dis. 11:113.

Martini, M., I. Altomonte, F. Mancianti, S. Nardoni, L. Mugnaini, and F. Salari. 2014a. A preliminary study on the quality and safety of milk in donkeys positive for Toxoplasma gondii. Animal http:// dx.doi.org/http://dx.doi.org/10.1017/S1751731114001980.

Martini, M., I. Altomonte, and F. Salari. 2014b. Amiata donkeys: Fat globule characteristics, milk gross composition and fatty acids. Ital. J. Anim. Sci. 13:123-126.

Monti, G., E. Bertino, M. C. Muratore, A. Coscia, F. Cresi, L. Silvestro, C. Fabris, D. Fortunato, M. G. Giuffrida, and A. Conti. 2007. Efficacy of donkey's milk in treating highly problematic cow's milk allergic children: An in vivo and in vitro study. Pediatr. Allergy Immunol. 18:258-264.

Pearson, R. A., and M. Ouassat. 2000. A guide to live weight estimation of body condition scoring of donkey. Centre for tropical veterinary medicine. University of Edinburgh, Edinburgh, UK. http://www.cd3wd.com/cd3wd_40/LSTOCK/001/Equines/ Condition\%20Scoring\%20Donkeys/Condition \% 20Scoring\% 20 Donkeys.pdf.

Salimei, E., and F. Fantuz. 2012. Equid milk for human consumption. Int. Dairy J. 24:130-142.

Salimei, E., F. Fantuz, R. Coppola, B. Chiofalo, P. Polidori, and G. Varisco. 2004. Composition and characteristics of ass's milk. Anim. Res. 53:67-78.

Sargentini, C., R. Tocci, L. Andrenelli, and A. Giorgetti. 2012. Preliminary studies on hoof characteristics in Amiata donkey. Ital. J. Anim. Sci. 11:123-127.

SAS Institute. 2002. JMP User's Guide. Version 5.0. SAS Institute Inc. Cary, NC. 